\title{
Şehri Hayal Etmek: İstanbul Tahayyülleri
}

\section{Olcay Akyıldız* Zeynep Uysal ${ }^{* *}$}

İstanbul, kat kat, üst üste yığılmış tarihler, kimlikler, kültürlerle biçimlenmiş bir şehir. İstanbul'un çok katmanlılı̆̆ı sadece tarihselliğinden kaynaklanmaz. Bugün içinde yaşarken de farklı hayatları, birbirinden uzak dünyaları, benzersiz insan portrelerini hem katmanları arasında hem de yan yana tutar. Bu hâli sadece şehrin büyük ya da kozmopolit oluşuyla da açıklayamayız. İstanbul, birbirine değen, birbirinden uzak, birbirini acıtan, birbirini aşkla seven, birbirinden kıyasıya nefret eden, umursamaz, hassas, nasırlı, kırılgan hayatların şehridir. Tarihte de böyledir bu. Şehre yapılanların şiddeti ise yüzyıllar geçtikçe artar. Bugün bu karmaşanın içinde bir uyum yakalamak, yükselen gökdelenlerin arasında nefes almak, tarihsel doku, sembolik binalar birer birer yıkılır ya da işlevleri dönüştürülürken şehirle barışık olmak gittikçe zorlaşmaktadır. Oysa şurası da bir gerçektir ki küsülen şehir değil, şehri değiştiren zihniyet olmalıdır. Nasıl ki şehri hayal eden de arzu nesnesine dönüştüren de onu yapan, yıkan ve tahayyül eden öznenin bakışıdır; şehre yüklenen anlamlar da bağlamdan ve siyasetten bağımsız değildir. Biz de bu dosyada İstanbul'u, şehrin de bir failliği olduğunu görmezden gelmeden ama daha ziyade onu dillendiren, temsil eden bakışa odaklanarak ele almaya çalıştık.

Bir arzu nesnesi olarak İstanbul'un farklı yüzleri, çok çeşitli imgeleri, edebiyattan sinemaya birçok alanda metinsel düzlemde temsil edilmiştir. Bu anlamda metinlerarası izleri de katmanları arasında taşıyan bir şehirdir İstanbul. Bu metinlerarası izler şehrin birbirinden ayrılmaz efsaneleri gibi öylesine karmaşık ve ayrıştırılamaz bir "halita"dır ki hayali veya gerçek tarihi belgeler ile şehir efsaneleri âdeta diyalojik bir düzlemde çatışırlar. İstanbul, bireysel ve toplumsal tahayyüllerin etkileşimiyle biçimlenen, dinamik bir makinadır; hem o tahayyüllerden beslenen hem onları ögütüp yok eden hem de yeni hayallere göz kırpan tehlikeli bir makina. İstanbul'un hikâyelerini, metinsel tahayyülle içinde yaşanılan mekânın kesişimlerini, zihinde kurgulananla metinsel temsilin ilişkisini anlamaya çalışmak aslında şehrin kendisini anlamanın yolunu açmaktadır. Mekânlarla ve şehirlerle kurduğumuz ilişki, fiziksel varoluşlarından bağımsız olarak onlara yüklenen aşkın anlamlarla da belirlenir. Örneğin 1960'lı yıllarda çekilmiş bir Yeşilçam filminde, köyünden kalkıp İstanbul'a gitmeyi hayal eden bir köylü ağız dolusu "İstanbul" derken bir somutşehirden ziyade "taşı toprağı altın" bir hayalşehirden söz etmektedir. Benzer biçimde bir on altıncı yüzyıl gazelinde sevgilinin temsiline dönüşen, ulaşılmaz, büyülü bir şehir manzarası ile yirminci yüzyıl başının işgal İstanbul'unda karşı yakayı seyrederken, içinde bulunduğu Avrupa yakasına, Beyoğlu'na lanetler okuyan karakterin tahayyülü giderek başkalaşmaktadır.

İstanbul'un edebi temsilleri tam da bu başkalaşımı, her an değişen görüntüleri gösterip durmaktadır. Şehrin çok katmanlılığı, duygusal yükü, hızla değişen, alttaki katmanların arasına gömülen kültürel, toplumsal mekânları, metinsel temsille kayda geçmiş olur. Örneğin Tevfik Fikret'in Sis şiirinde İstanbul bir iktidarlar şehri olarak yerden yere vurulur. İstanbul'a çok kızgın ama aynı zamanda büyük bir acı içindedir şiir öznesi. "Ey sahn-1 mezâlim... Evet, ey sahn-1 garrâ / Ey sahne-i zî-şa'şaa-i hâile-pirâ!" derken aslında bütün şiir boyunca şaşaayı, parlaklığı̆, sonsuz bir güzelliği, ölümle, katliamlarla, zulümlerle birlikte anar.' Sadece istibdadın değil, gelmiş geçmiş bütün iktidarların zulüm sahnesi olduğu için büyük bir öfke duyar İstanbul'a. Fikret'in şiirinde bu öfke ve acının telafisi yoktur. İstanbul örtünmeli, zulümlere sebep olan güzelliğini gizlemeli ve müebbet uyumalıdır.

\footnotetext{
* Boğaziçi Üniversitesi, olcayak@boun.edu.tr

** Boğaziçi Üniversitesi, zeynep.uysal@boun.edu.tr

1 Tevfik Fikret, Rubab-ı Şikeste (İstanbul: Dergâh Yayınları, 2017).
} 
128 Aynı şiirde şehir olağanüstü güzel, herkesi etkisi altına alan güçlü ama duyarsız bir kadın imgesiyle biçimlendirilir: "Şarkın ezelî hâkime-i câzibedârı; [...] / Ey köhne Bizans, ey koca fertût-1 müsahhir / Ey bin kocadan arta kalan bîve-i bâkir" dediği, hem büyüleyen hem öfke duyulan, hem sahip olunmak hem görülmemek istenen dişil bir imgedir. Şiir öznesinin temellük edemediği ama temellük edildiği için öfkelendiği şehrin dişilleştirilmesi kaçınılmazdır. Bu dişilleştirme hamlesinin şarkiyatçı külliyatla ilişkisi aşikârdır. Bu tür bir ilişki yazar ve şairlerde kimi zaman doğrudan bir etki olarak çıkar karşımıza, kimi zamansa onların İstanbul'u kuran hayal dünyalarının kaynakları ve dolaşım yolları, şehrin dehlizleri gibi takip edilemez bir hâl alır.

Esasen mekânı bir cennet-mekândan felaket mekânına dönüştüren, daha genel anlamda mekân algısını biçimlendiren, bireyin bakışıdır. Ahmet Hamdi Tanpınar, İstanbul için şöyle der: "Bu kelimeden taşan aydınlık bizim için daha ziyade kendi ruh haletlerimize göre seçtiğimiz, mazi hatıralarının, hasretlerin aydınlığıdır." Ruh hâli ile şehre ait görüntülerden devşirilen hatıralar arasındaki ilintinin şehri belirlediğini vurgular bir bakıma. ${ }^{3}$ Yani esas olan şehrin ne olduğu değil, algılayan öznenin ne gördüğüdür. Ve tabii özne sadece aydınlığı görmez.

Diğer bir deyişle, şehrin edebiyattaki temsiline baktığımızda gördüğ̈̈müz, cennet-mekân olarak tahayyül edilen şehirden felaket mekânına, dehşet-mekâna dönüşen bir şehir manzarasıdır. Şehir anlatıları, bireysel bir ruh hâlinden yansıyanın ötesine geçerek, daha ideolojik bir pozisyondaki öznenin bakışını da işaret eder. Tanpınar'ın Huzur'unda Mümtaz karakteri İstanbul sokaklarını dolaşırken, bir yandan Mümtaz'ın içinden, filtresinden yansıyan biricik öznelliğinin izlerini, mutluluk arayışından varoluşsal krizlerine uzanan parçalanmışlı̆ı̆ını görür, diğer yandan da Tanpınar'ın kültürel devamlılık fikrinin işaretleriyle biçimlenen, modernleşme krizinin, kimlik arayışının her yana sindiği, savaşların yıktığı, ezdiği bir şehrin manzarasını yine Mümtaz’ın gözünden izleriz-aynı İstanbul 1940 kuşağı toplumcu şairlerinin dizelerinde ya da biraz daha sonra toplumcu gerçekçi romanlarda, fabrikaları ve fakir mahalleleri ile başka bir filtreden yazılacak, aynı manzaralar başka bir duyarlıkla ele alınacaktır.

Orhan Pamuk Istanbul: Hatıralar ve Şehir'de Tanpınar'in ruh hâline yaptığı vurguya çok benzeyen bir cümle kurarken öznenin bakışının görünen manzarayı nasıl ifşa ettiğini, seyredileni nasıl bir yordamla kelimelere döktüğünü gösterir:

Şehrin manzaralarına bakmak, sokaklarda yürüyerek, gemiyle gezinerek, İstanbul'un verdiği duyguları görüntülerle birleştirmektir, ama gezinerek şehrin manzaralarını seyretmek bu değildir yalnızca, bir de içinde bulunduğunuz ruh hâlini şehrin size verdiği görüntülerle birleştirebilmektir. Bunu hünerle ve içtenlikle yapmak, insanın hafızasında şehrin görüntülerini en derin ve içten duygularla, acıyla, kederle, hüzünle ve zaman zaman mutluluk, yaşama sevinci ve iyimserlikle birleştirmekti. ${ }^{4}$

Tıpkı Tanpınar'ın cümlesinde olduğu gibi, görüntüyle ruh hâlini birleştirme edimi hafızada gerçekleşir. Hafızada kayıtlı hatıraları harekete geçiren görüntüler birbirinden başka duygulara karşl1ık gelecek, böylece her an hareket eden, dinamik ve değişen mekân, görüntüye zaptolmuş, sabitlenmiş ânın aksine, öznenin zihnindeki duygusal hareketle yeni anlamlar bulacaktır.

Şehrin sanatta temsili üzerine düşünürken peşinde olduğumuzun bir gerçeklik arayışı olmadığının bilincindeyizdir. İstanbul gibi doğrudan maruz kaldığımız bir şehir üzerine daha mesafeli bir söz söylemeye çalışırken sorulacak soruların başında, şehri temsil eden öznelerin (yazar, şair, ressam ya da fotoğrafçıların) şehirle kurdukları ilişkinin dayanaklarının ne oldu$\breve{g u}$, niyetlerinin nasıl belirlendiği gelmektedir. Bundan kasıt, örneğin mesneviyi kaleme alan şairin, şehre doğrudan bakmaktan ziyade padişahı yüceltmek amacı ile şehri araçsallaştırdığ 1 bir tahayyül kurmasıdır. Fakat bu araçsallaştırma stratejisi de bize dönemin şehre bakışına dair pek çok ipucu verir.

2 Ahmet Hamdi Tanpınar, Beş Şehir (ìstanbul: MEB, 1989), 141. Vurgular bize ait.

3 Zeynep Uysal, "Şehri Yeniden Yazan Edebiyat: Cumhuriyet Döneminden Beş İstanbul," Antik Çă̆’dan XXI. Yüzylla

Büyük İstanbul Tarihi, c. 7, Edebiyat Kültür ve Sanat, der. Hatice Aynur (İstanbul: IBBB Yayınları, 2015), 2.

4 Orhan Pamuk, istanbul: Hatıralar ve Şehir (İstanbul: Yapı Kredi Yayınları, 2012), 320. 
Şehrin çok daha neonlu, interaktif ve değişken imgelerinin zihnimizi işgal ettiği, reklam panolarında siyasi bir meta olarak pazarlandığı bugünlerde sözünü edebileceğimiz ise tahayyül kelimesinin romantik çağrışımlarını dışarıda bırakan daha vahşi bir pazardır. Şehrin doğasını, iklimini, yaşam alanlarını hoyratça işgal eden, betonlaştıran zihniyet yapısı İstanbul'un üst üste yığılmış katmanlarında gizlenen hayat hikâyelerini sonsuza dek yok etmeyi amaçlamış gibidir. YILLIK: Annual of Istanbul Studies'in Meclis bölümünde yer alan bu küçük dosyadaki Murat Germen fotoğrafları bu rant dünyasını tek tek fotoğraf karelerinde çarpıcı bir biçimde ortaya koyar. İstanbul'un içinde yaşadığımız şu günlerdeki dönüşümü kentin zamansız, tarihsiz, kültürsüz anlarını kaydetmiş gibidir. Fotoğraflayan göz hem kaydeder, arşiv oluşturur hem de itiraz eder. Sözü olan fotoğraflardır elbette bunlar. Şehir kesilip biçilmektedir; Germen ise durduramayacağı bu eyleme şerh düşer.

Germen'in fotoğraflarıyla şehrin bugününü izlediğimiz sayfalar geçmiş zamanın İstanbul'unun edebi temsiline odaklanan üç makaleyle tamamlanır. Selim Sırrı Kuru bugünün okuru için şaşırtıcı bir ayrımla Galata ve İstanbul'un iki ayrı şehir olarak gazellerde nasıl yer aldığı ile ilgilendiği "iki Şehrin Şiiri: Gazelde İstanbul ve Galata İkilisi” başlıklı yazısında, İstanbul'un fethinden itibaren bu ikiliğin izini sürerek kaynaklarına ve nedenlerine bakar. Gerçekçi betimlemelerden ziyade bir karşıtlık işlevi ile gazellerde yer alan Galata-İstanbul ilişkisi, tarihsiz ve tekrarlarla ilerlediği düşünülerek yapılan kalıplaşmış divan şiiri tanımlarını yıkarken hem tarihsel bir değişimi gözler önüne serer hem de öznenin mekânla ilişkisinin, başta da belirttiğimiz arzu ve hayal ekseninde nasıl bir dinamikle işlediğini ortaya koyar. Galata âdeta bir öteki şehir olarak onu anlatan öznenin arzularını kışkırtırken, bir kez daha şehrin farklı katmanları, tarihsel dönemleri gibi, bu defa ikili bir zıtlık olarak kurulan farklı coğrafyalarının temsilinin birbirine nasıl karıştığını gösterir.

Hatice Aynur'un “Tatavlalı Mahremînin Şehnâmesi’nde Suriçi İstanbul'u” başlıklı yazısı hem doğduğu semtle anılması hem de doğrudan İstanbul'u anlatışı ile dikkat çeken Mahremî̀nin on altıncı yüzyıl İstanbul'una bakar. Tarihî olaylarla eş zamanlı olarak şairin başından geçenlerin de anlatıldığ 1 Şehnâme'de İstanbul özel bir yer tutar. 549 beyitte doğrudan İstanbul'a yer verilir, ancak Mahremînnin asıl amacı üç farklı padişahı överek metnini onlara sunmaktır. Dolayısıyla şehir anlatıları da esasen bu amaca bağlanır. Fakat bu makro hedefin yanı sıra, Mahremînin kişisel şehir deneyimlerini de bu beyitlerde izlemek mümkündür. Belli kalıplar içerisinde dar alanda kalem oynattığı için döneme ve mekâna dair fazla bir bilgi edinilemeyeceği genel geçer yargısının aksine, bu divan şairinin dizelerinde İstanbul'u da okur, izleriz. Ve o İstanbul bir yandan araçsallaştırılarak yüceltilirken diğer yandan öznel bir bakışla da dillendirilir.

Dosyadaki "Hangi İstanbul? Ahmet Hamdi Tanpınar ve Orhan Kemal'in Gözünden Şehre Bakmak" başlıklı son yazı Handan İnci'ye ait. Aynı dönemlerde yaşayıp birbirine taban tabana zit dünya görüşleriyle yazmış olan Ahmet Hamdi Tanpınar ile Orhan Kemal'in İstanbul'unu karşılaştırdığı yazısında İnci, İstanbul denince çoğu okurun aklına gelen Tanpınar'ın hülyalı bakışının İstanbul'una karşılık Tanpınar'ın anlatmadığı, onun filtresinden geçmeyen bir başka İstanbul, İstanbullar olduğuna işaret etmiş olur. Bu anlamda "hangi İstanbul?" sorusunu sorarak şehrin çok katmanlılığı ve kozmopolitliğinin gizlediği farklı hayat manzaralarına, neredeyse aynı zamanlarda yazan bu iki yazarın farklı bakışıyla cevap arar.

"Şehri Hayal Etmek" başlıklı bu dosya, klasik Osmanlı şiirindeki İstanbul temsillerinden cumhuriyet dönemi romancılarının şehri algılayışına uzanan bir hat çizer. İstanbul'un çok çeşitli ve zengin edebi temsillerinin belirli dönemlerdeki örneklerini sunan üç yazı, burada tartışılmayan birçok temsil biçimi, çeşidinin de odaklandığı dünyalara, bakış açılarına işaret etmektedir. Murat Germen'in fotoğrafları ise farklı bir temsil düzleminde, zamanın ötesine geçerek şehre bakan gözün mekânla ilişkisini ve öznel bakışını çarpıcı bir biçimde ortaya koyar. İstanbul'a bakan bu yazıları ve fotoğrafları birleştiren, şehrin zamana karşı süregiden çok katmanlı, dinamik yapısı ve dönüşen mekâna kaydolan hayat hikâyeleridir. 